\title{
Nutritional Properties of Some Selected Date Palm (Phoenix dactylifera L) Land Races in Nigeria
}

\author{
Yahaya Sadiq Abdulrahman, 1, *, Falusi Olamide Ahmed ${ }^{2}$, Gana Saba Andrew ${ }^{3}$, \\ Daudu Oladipupo Abdulazeez Yusuf ${ }^{2}$, Abdulkarim Bello Muhammad ${ }^{4}$, \\ Osaro-odin Precious Eloghosa ${ }^{1}$, Aliyu Rahamat Hussaini ${ }^{4}$ \\ ${ }^{1}$ Nigerian Institute for Oil Palm Research, Date Palm Research Substation, Dutse, Nigeria \\ ${ }^{2}$ Department of Plant Biology, Federal University of Technology, Minna, Nigeria \\ ${ }^{3}$ Department of Crop Production, Federal University of Technology, Minna, Nigeria \\ ${ }^{4}$ Department of Plant Science and Biotechnology, Nassarawa State University, Keffi, Nigeria \\ Email address: \\ headboy4real004@gmail.com (Y. S. Abdulrahman) \\ ${ }^{*}$ Corresponding author
}

\section{To cite this article:}

Yahaya Sadiq Abdulrahman, Falusi Olamide Ahmed, Gana Saba Andrew, Daudu Oladipupo Abdulazeez Yusuf, Abdulkarim Bello Muhammad, Osaro-odin Precious Eloghosa, Aliyu Rahamat Hussaini. Nutritional Properties of Some Selected Date Palm (Phoenix dactylifera L) Land Races in Nigeria. World Journal of Food Science and Technology. Vol. 4, No. 1, 2020, pp. 1-7. doi: $10.11648 /$ j.wjfst.20200401.11

Received: January 7, 2020; Accepted: February 3, 2020; Published: February 19, 2020

\begin{abstract}
The chemical constituents present in plants have been reported to vary with the geographical location of the plants. This investigation assessed the nutritional composition of some selected date fruits from the experimental gene pool in dutse, Nigeria in order to investigate any uniqueness relative to date palms cultivated in other regions. The proximate analysis of the date fruits were quantitatively analyzed for carbohydrates, protein, lipids, fiber, moisture, sucrose, glucose and fructose. The mineral contents were analyzed using atomic absorption spectrophotometer (AAS). The highest moisture content were recorded for accession R13P5 (7.65 \pm 0.03$)$. Moreover, carbohydrate and protein content was found to be highest in accessions R5P24 (64.55 \pm 5.73$)$ and R4P29 (7.13 \pm 0.19$)$ respectively. Similarly the ash, fiber and lipid contents were highest in accessions R5P8, R14P21 and R5P24 respectively. Considerable amounts of sucrose, glucose and fructose were recorded in all the accessions. The mineral contents analyzed indicated good sources of minerals such as calcium, magnesium, sodium, potassium and phosphorus. The present finding helps in understanding the nutritional status of different accessions in some Nigerian date palm fruits which can serve as a baseline for selection in improvement of the crop for the nutritional health benefits.
\end{abstract}

Keywords: Nutritional Composition, Proximate Analysis, Date Fruits, Accessions, Gene Pool, Minerals

\section{Introduction}

Date palm (Phoenix dactylifera $\mathrm{L}$ ). Is a monocotyledonous woody perennial fruit tree belonging to the Arecaceae family. Date palm fruits are rich sources of carbohydrates, dietary fibers, certain essential vitamins and minerals. Date pits are also an excellent source of dietary fiber and contain considerable amounts of minerals, lipids and protein, [1]. The nutritional value of dates is ideally a high energy food as they have a high content of sugar [2, 3]. Fruit of Date Palm can be used as alternative source of food and vitamins and can be incorporated into diet because of its richness in nutritional composition. [4]

In Nigeria, date palm is one of the most important tree crops of Sahel, Sudan and Guinea Savannah ecologies where it has remained restricted within compounds homesteads and orchards in the Northern part of the country i.e above latitude $10^{\circ} \mathrm{N}$ [5]. The date palm in Nigeria is essentially cultivated for its edible fruits which are very nutritious and energy producing, [6].

Although the date palm is not indigenous to Nigeria, but with over 400 years of its existence, the crop has been cultivated for sufficiently long time to have acquired agro climatic adaptation and so evolved as land races. Most 
national collections of date palms germplasm rely on primarily on these land races. However, several collections missions have been undertaken to capture these land races by the Nigerian Institute For Oil Palm Research (NIFOR) for date palm germplasm conservation and crop improvement to gene pools (from gene pool 1-5) which constitutes several collection missions from the date palm growing states in Nigeria.

The objective of this study was to provide information on nutritional composition in some selected fruits of some date palm land races from the experimental gene pools in dutse, Nigeria. In this study, the proximate, mineral and sugar content analysis were determined in order to quantify the level of these parameters so as to select the desirable accessions which can be useful for future breeding programmes.

\section{Material and Methods}

\subsection{Sample Collection and Preparation}

Date palm fruits were collected from the experimental field of the Nigerian Institute for Oil palm research (NIFOR), date palm research substation in dutse, jigawa state of Nigeria, during the dry season fruit harvest between February and March, 2019. The fruits were oven dried at $55^{\circ} \mathrm{C}$ for 24 hours. The dried sample were grounded into powder using pestle and mortar, and then sieved through 20-mesh sieve. The powder was used for analysis.

\subsection{Determination of Moisture Content}

Sample containers were dried in a hot - air oven at $105^{\circ} \mathrm{C}$ for 30 minutes and weighed. Exactly $1.0 \mathrm{~g}$ of ground samples were placed in the oven-dried containers and weighed. The ginger/garlic samples in the containers were oven-dried to a constant weigh at $105^{\circ} \mathrm{C}$ in three (3) hours. After three (3) hours, the samples were allowed to cool in a desiccators and weighed. The loss in weight after drying for three (3) hours was determined accordingly. Moisture content of the coal samples were calculated:

$$
\text { Moisture }(\%)=\frac{\text { loss in weight after drying }}{\text { Initial samples weight. }} \times 100
$$

\subsection{Ash Content Analysis}

$1.0 \mathrm{~g}$ of each garlic/ginger samples were weighed from the oven-dried sample from moisture content determination. Crucibles were pre-heated in a muffle furnace to exactly $550^{\circ} \mathrm{C}$, cooled in desiccators and weighed. The oven-dried samples were then transferred into the crucibles, placed in a muffle furnace and the temperature raised to $550^{\circ} \mathrm{C}$. After two (2) hours of uninterrupted heating at $550^{\circ} \mathrm{C}$, the crucibles were removed with tong and transferred into the desiccator for cooling. The cooled crucibles were weighed and the weight of the sample left was determined.

The Ash Content is calculated as:

$$
\operatorname{Ash}(\%)=\frac{\text { weight of ash }}{1 \mathrm{~g}(\text { oven }- \text { dried weight })} \times 100
$$

\subsection{Crude Protein Analysis}

$2.5 \mathrm{~g}$ of dried and ground samples were weighed into the digestion tubes. $15 \mathrm{~g} \mathrm{Na}_{2} \mathrm{SO}_{4}, 1 \mathrm{~g} \mathrm{CuSO}_{4}$, one or two solemnized boiling granules and $25 \mathrm{ml}$ of concentrated $\mathrm{H}_{2} \mathrm{SO}_{4}$ was added to the tube. It was digested at about $400^{\circ} \mathrm{C}$ until solution was almost colorless $(2 \mathrm{hrs}$ for inorganic material) and then at least a further 30 minutes. It was cooled down, $200 \mathrm{ml}$ of water was cautiously added. $100 \mathrm{ml} 0.1 \mathrm{~N}$ $\mathrm{HCl}$ was pipette into a $500 \mathrm{ml}$ conical flask, $1 \mathrm{ml}$ Conway's indicator was added and the flask placed under the condenser of the distillation apparatus ensuring that the condenser tip is immersed in the acid solution. (volume of standardized $\mathrm{HCl}$ used in distillation may be varied according to the expected nitrogen content of the sample). To the Kjeldahl tube containing the digested samples, $100 \mathrm{~mL}$ of $50 \% \mathrm{NaOH}$ solution was slowly added down the side of the Kjeldahl tube so that it formed a layer underneath the digestion mixture. The digestion mixture was immediately transferred to the distilling bulb of the distillation apparatus and corked. It was heated until all ammonia passed over into the standard acid. Approximately $150 \mathrm{~mL}$ was collected. Excess standard $\mathrm{HCl}$ in distillate was titrated with $\mathrm{NaOH}$ standard solution until colour changed from purple to green indicating end point.

Percentage nitrogen was calculated (wet weight basis) as follows:

$$
\begin{gathered}
\% \text { Nitrogen }(\text { wet })=(\text { A-B }) \times 1.4007 \times 100 / \text { weight }(g) \text { of } \\
\text { sample }
\end{gathered}
$$

Where:

1. $\mathrm{A}=$ vol. $(\mathrm{mL})$ std. $\mathrm{HCl} \times$ normality of std. $\mathrm{HCl}$

2. $\mathrm{B}=$ vol. $(\mathrm{mL})$ std. $\mathrm{NaOH}$ x normality of std. $\mathrm{NaOH}$

Nitrogen content on dry basis was calculated (when moisture content is known) as follows:

$$
\begin{gathered}
\% \text { Nitrogen }(\text { dry })=\% \text { Nitrogen }(\text { wet }) \times 100 /(100-\% \\
\text { moisture })
\end{gathered}
$$

Calculate the percentage protein (wet or dry basis) as follows:

$$
\% \text { PROTEIN }=\% \text { nitrogen } \times 6.25
$$

Where 6.25 is the protein-nitrogen conversion factor.

\subsection{Crude Lipid Analysis}

$2 \mathrm{~g}$ was weighed from the oven dried sample from moisture content determination into a thimble (W1) and the weight of empty thimble (W0). It was further dried in the oven for $5 \mathrm{~h}$ at $100^{\circ} \mathrm{C}$. Beakers to be used for fat determination were dried for about $1 \mathrm{~h}$ at $100^{\circ} \mathrm{C}$ and cooled in a desiccator. The weights were taken and recorded (W2). The thimble containing the sample was placed in a soxhlet unit connected to a condenser and a heating flask. About $400 \mathrm{~mL}$ of petroleum ether was poured into the flask in the extraction unit. The heating mantle was set to $60^{\circ} \mathrm{C}$ and 
extraction was carried out for $3 \mathrm{~h}$. The solvent containing the extracted lipid was poured into the dried beaker and evaporated in a stream of air at room temperature until there was no further weight loss. The beaker and exract was weighed (W3).

$\%$ Crude lipid $=(\mathrm{W} 3-\mathrm{W} 2) /$ weight $(\mathrm{g})$ of sample

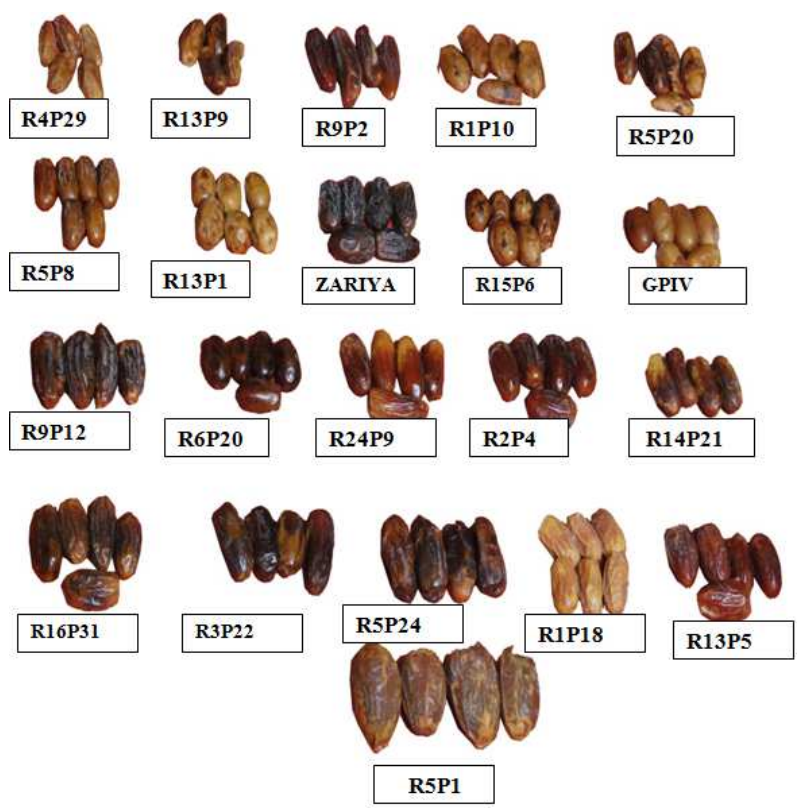

Figure 1. The fruits of the twenty-one accessions collected and studied.

\subsection{Crude Fiber Analysis}

$1 \mathrm{~g}$ of the sample was weighed from the oven dried sample from moisture content determination. $==>\mathrm{W} 1$. $1.25 \%$ sulfuric acid was added to the $150 \mathrm{ml}$ notch, after preheating by the hot plate in order to reduce the time required for boiling. 3-5 drops of n-octanol was added as antifoam agent. It was boiled for 30 minutes exactly from the onset of boiling. Sulfuric acid was drained off. It was washed three times with $30 \mathrm{ml}$ (crucible filled up to the top) of hot deionized water and drained. $150 \mathrm{ml}$ of preheated potassium hydroxide $(\mathrm{KOH}) 1.25 \%$ and $3-5$ drops of antifoam was added. It was boiled for 30 minutes. It was filtered and washed as point 6 . It was washed again with cold deionized water aimed to cool the crucibles and then washed three times with $25 \mathrm{ml}$ of acetone. The crucibles were dried in an oven at $105^{\circ} \mathrm{C}$ for an hour or up to constant weight. It was allowed to cool in a desiccator and then weighed. This weight (W2) represents the crude fiber plus ash content in comparison to initial weight.

The percentage crude fiber Calculated as:

$$
\% \text { Crude fiber }=(\mathrm{W} 2-\mathrm{W} 1) \times 100 / \mathrm{W} 1
$$

\subsection{Carbohydrate Content Analysis}

Percentage $(\%)$ carbohydrate was calculatedas $=100-(\%$ $\mathrm{CL}+\% \mathrm{CP}+\%$ ash $+\% \mathrm{CF}+\%$ Moisture)

$\mathrm{CL}=$ Crude lipid

$\mathrm{CP}=$ crude protein

$\mathrm{CF}=$ crude fiber

\subsection{Sugars Determination}

Samples of the date fruits were taken and three replicates of each were used. Non-reducing sugar (sucrose) was calculated as the difference between total sugars and reducing sugars. Fructose and glucose were determined using an enzymatic glucose analyzer [7].

\subsection{Statistical Analysis}

Data were expressed as mean \pm standard error. The data obtained were subjected to Analysis of variance (ANOVA) test to determine whether there were significant differences, and Duncan multiple range test (DMRT) was used to separate the means among the twenty-one date accessions studied.

\section{Results}

\subsection{Proximate}

The proximate analysis of date palm (Phoenix dactylifera) fruit revealed the presence carbohydrates, protein, ash, fiber, lipid, calcium, magnesium, Sodium, phosphorus, potassium, Table 1. The presence of these constitutes gives an indication of the nutritional value of the date palm fruits. From the results obtained in this study, it was observed that accession R13P57 had the highest moisture content of $7.65 \%$, this value was significantly the same with ZARIYA but significantly different from all other accessions. The lowest moisture content was observed in accession R16P31 with a mean of $2.25 \%$. However no significant differences were observed in the accessions R6P20, R5P8, R5P24, R1P18, R7P1, R24P9, and R9P12.

The least carbohydrate content was recorded in accession R5P24 with the mean 64.55 and the highest was observed in accession R9P12 with the value of 82.85 , this value was significantly the same with the value obtained from R2P4 and GPIV but are significantly different from all other accessions.

The ash content was significantly different. for accessions R5P8 and R9P2, they were significantly higher than other accessions, however, no significant differences were observed in accessions R6P20, R5P24, R1P10, R14P21, R15P6, R24P9, R5P20, R13P1 and R9P12 statistically.

The highest protein content was observed in accessions R4P29 with the mean $7.13 \%$, this value was significantly different from all other accessions while the least was observed in accession R5P8 with the mean 3.36\% and it was significantly different from all other accessions.

The result of the fiber content showed that accession R14P21 had the highest fibre with a mean of $12.20 \%$. This value was significantly different from all other accession at $\mathrm{P}<0.05$. The least was observed in accessions R5P8, R13P1, R5P20 with their means $2.1,2.2,2.13$ respectively but were different significantly from all other accessions.

The lipid content was highest in accession R5P24 with the mean 5.46 followed by accession R16P31 with the mean 4.93 , but they are significantly different from all other accessions at $\mathrm{P}<0.05$ statistically. 
Table 1. Proximate Analysis of the 21 date palm accessions studied.

\begin{tabular}{|c|c|c|c|c|c|c|}
\hline ACCNS & MOIST & ASH & PROTEIN & FIBRE & LIPID & CARB \\
\hline R13P9 & $3.75 \pm 0.04^{\mathrm{f}}$ & $1.56 \pm 0.04^{\mathrm{f}}$ & $3.81 \pm 0.16^{\mathrm{f}}$ & $8.47 \pm 0.41^{\mathrm{c}}$ & $3.39 \pm 0.31^{\mathrm{bc}}$ & $68.05 \pm 5.81^{\mathrm{cd}}$ \\
\hline R16P31 & $2.25 \pm 0.01^{j}$ & $2.16 \pm 0.1^{\text {bcde }}$ & $5.4 \pm 0.32^{c}$ & $5.56 \pm 0.3^{\mathrm{e}}$ & $4.93 \pm 0.33^{\mathrm{ab}}$ & $69.98 \pm 5.78^{\text {bcd }}$ \\
\hline R6P20 & $2.53 \pm 0.01^{\text {hij }}$ & $2.44 \pm 0.03^{\mathrm{abcd}}$ & $4.37 \pm 0.24^{\mathrm{ef}}$ & $2.3 \pm 0.06^{\mathrm{fg}}$ & $2.97 \pm 0.57^{\mathrm{bc}}$ & $74.6 \pm 5.88^{\mathrm{abcd}}$ \\
\hline R5P8 & $2.54 \pm 0.01^{\mathrm{hij}}$ & $2.7 \pm 0.06^{\mathrm{a}}$ & $3.36 \pm 0.19^{\mathrm{h}}$ & $2.1 \pm 0.12^{\mathrm{g}}$ & $2.93 \pm 0.6^{\mathrm{bc}}$ & $75.14 \pm 5.8^{\mathrm{abcd}}$ \\
\hline R3P22 & $4.6 \pm 0.36^{\mathrm{e}}$ & $2.4 \pm 0.06^{\mathrm{abcd}}$ & $6.26 \pm 0.26^{\mathrm{b}}$ & $2.9 \pm 0.12^{\mathrm{fg}}$ & $4.19 \pm 1.19^{\mathrm{abc}}$ & $67.8 \pm 5.79^{\mathrm{cd}}$ \\
\hline $\mathrm{R} 5 \mathrm{P} 24$ & $2.47 \pm 0.02^{\text {hij }}$ & $2.42 \pm 0.06^{\mathrm{abcd}}$ & $5.29 \pm 0.19^{c}$ & $6.4 \pm 0.17^{\mathrm{de}}$ & $5.46 \pm 0.44^{\mathrm{a}}$ & $64.55 \pm 5.73^{\mathrm{d}}$ \\
\hline $\mathrm{R} 1 \mathrm{P} 18$ & $2.62 \pm 0.05^{\mathrm{h}}$ & $1.83 \pm 0.05^{\text {ef }}$ & $5.25 \pm 0.22^{\mathrm{c}}$ & $9.7 \pm 0.17^{b}$ & $3.04 \pm 0.57^{\mathrm{bc}}$ & $72.38 \pm 2.14^{\mathrm{abcd}}$ \\
\hline R1P10 & $2.29 \pm 0.01^{\mathrm{ij}}$ & $2.42 \pm 0.05^{\mathrm{abcd}}$ & $3.82 \pm 0.15^{\mathrm{fgh}}$ & $6.8 \pm 0.17^{\mathrm{de}}$ & $4.83 \pm 0.57^{\mathrm{abc}}$ & $75.24 \pm 2.67^{\mathrm{abcd}}$ \\
\hline R7P1 & $2.7 \pm 0.06^{\mathrm{h}}$ & $1.83 \pm 0.03^{\mathrm{ef}}$ & $4.6 \pm 0.32^{\mathrm{de}}$ & $5.5 \pm 0.26^{\mathrm{e}}$ & $3.39 \pm 0.55^{\mathrm{bc}}$ & $80.39 \pm 0.17^{\mathrm{ab}}$ \\
\hline $\mathrm{R} 14 \mathrm{P} 21$ & $3.68 \pm 0.02^{f}$ & $2.55 \pm 0.16^{\mathrm{ab}}$ & $4.16 \pm 0.09^{\mathrm{efg}}$ & $12.2 \pm 0.55^{\mathrm{a}}$ & $4.4 \pm 0.59^{\mathrm{abc}}$ & $70.41 \pm 0.4^{\mathrm{bcd}}$ \\
\hline R15P6 & $6.55 \pm 0.03^{c}$ & $2.46 \pm 0.04^{\mathrm{abcd}}$ & $6.03 \pm 0.05^{\mathrm{b}}$ & $2.82 \pm 0.52^{\mathrm{fg}}$ & $3.84 \pm 0.6^{\mathrm{abc}}$ & $77.19 \pm 1.33^{\mathrm{abc}}$ \\
\hline R4P29 & $7.5 \pm 0.06^{\mathrm{a}}$ & $2.02 \pm 0.13^{\mathrm{de}}$ & $7.13 \pm 0.19^{a}$ & $7.16 \pm 0.53^{d}$ & $2.89 \pm 0.6^{\mathrm{bc}}$ & $75.37 \pm 0.96^{\mathrm{abcd}}$ \\
\hline GPIV & $5.04 \pm 0.03^{\mathrm{d}}$ & $2.04 \pm 0.16^{\text {cde }}$ & $3.78 \pm 0.13^{\mathrm{fgh}}$ & $3.61 \pm 0.5^{\mathrm{f}}$ & $3.5 \pm 0.61^{\mathrm{abc}}$ & $82.32 \pm 0.92^{\mathrm{a}}$ \\
\hline $\mathrm{R} 24 \mathrm{P} 9$ & $2.59 \pm 0.02^{\mathrm{hi}}$ & $2.52 \pm 0.51^{\mathrm{ab}}$ & $5.22 \pm 0.13^{\mathrm{cd}}$ & $11.67 \pm 0.61^{\mathrm{a}}$ & $3.97 \pm 0.31^{\mathrm{abc}}$ & $73.41 \pm 0.9^{\text {abcd }}$ \\
\hline ZARIY & $7.18 \pm 0.1^{b}$ & $2.11 \pm 0.06^{\text {bcde }}$ & $3.64 \pm 0.33^{\mathrm{gh}}$ & $2.36 \pm 0.36^{\mathrm{fg}}$ & $3.48 \pm 0.57^{\mathrm{abc}}$ & $80.36 \pm 1^{\mathrm{ab}}$ \\
\hline R9P2 & $5.23 \pm 0.15^{\mathrm{d}}$ & $2.65 \pm 0.04^{\mathrm{a}}$ & $6.08 \pm 0.09^{b}$ & $5.43 \pm 0.55^{\mathrm{e}}$ & $2.69 \pm 0.6^{\mathrm{bc}}$ & $76.53 \pm 1.18^{\mathrm{abc}}$ \\
\hline $\mathrm{R} 5 \mathrm{P} 20$ & $2.54 \pm 0.03^{\mathrm{hij}}$ & $2.49 \pm 0.08^{\mathrm{abc}}$ & $4.3 \pm 0.23^{\mathrm{efg}}$ & $2.2 \pm 0.57^{\mathrm{g}}$ & $4.62 \pm 0.59^{\mathrm{abc}}$ & $78.59 \pm 0.96^{\mathrm{abc}}$ \\
\hline R13P1 & $4.95 \pm 0.03^{\mathrm{d}}$ & $2.38 \pm 0.06^{\mathrm{abcd}}$ & $5.13 \pm 0.19^{\text {cd }}$ & $2.13 \pm 0.55^{\mathrm{g}}$ & $3.5 \pm 0.59^{\mathrm{abc}}$ & $79.49 \pm 1.04^{\mathrm{ab}}$ \\
\hline R13P5 & $7.65 \pm 0.03^{\mathrm{a}}$ & $1.81 \pm 0.1^{\mathrm{ef}}$ & $4.35 \pm 0.21^{\mathrm{ef}}$ & $5.63 \pm 0.53^{\mathrm{e}}$ & $4.49 \pm 0.57^{\mathrm{abc}}$ & $75.08 \pm 1.09^{\mathrm{abcd}}$ \\
\hline $\mathrm{R} 2 \mathrm{P} 4$ & $3.13 \pm 0.09^{\mathrm{g}}$ & $2.04 \pm 0.09^{\text {cde }}$ & $4.31 \pm 0.18^{\text {efg }}$ & $2.35 \pm 0.47^{\mathrm{fg}}$ & $4.18 \pm 0.59^{\mathrm{abc}}$ & $82.7 \pm 1.25^{\mathrm{a}}$ \\
\hline R9P12 & $2.57 \pm 0.06^{\mathrm{hi}}$ & $2.57 \pm 0.04^{\mathrm{ab}}$ & $3.76 \pm 0.26^{\mathrm{fgh}}$ & $2.89 \pm 0.58^{\mathrm{e}}$ & $4.11 \pm 0.57^{\mathrm{abc}}$ & $82.85 \pm 1.1^{\mathrm{a}}$ \\
\hline
\end{tabular}

Mean \pm standard error with different (s) letters in the same column are significantly differed at $\mathrm{P}>0.05$.

\subsection{Mineral Content}

The results of the mineral content of the fruits of date palm (Phoenix dactylifera) accessions are shown in table 2. Below:

The calcium content was highest in accession R24P9 (119.39), followed by accession R5P24 (102.17) and the least was observed in accession 68.83. This value was significantly different from all other accessions at $\mathrm{P}<0.05$.

The accession R5P24 had the highest magnesium content while the least was observed in accession R13P5. This value was significantly different from all other accessions at $\mathrm{P}<0.05$ level of significance.

The Sodium $(\mathrm{Na})$ content was least in accession R13P5 with the mean (6.20), while the highest sodium content was observed in accession R24P9, although there are significant differences in all the accessions at $\mathrm{P}<0.05$ level of significance.

In terms of potassium, the highest was recorded in accession R5P8, followed by accession R24P9 and the least was observed in accession R2P4. This value was statistically different from the value of all other accessions.

The phosphorus content was least in accession R3P22 with the mean 24.82 while the highest was recorded in accession R5P8with the mean (48.3) followed by accession R24P9 with the mean (46.8). But no significant differences were observed in accessions R16P31 and R2P4 statistically with their means (29.4 and 3.13).

Table 2. Mineral Analysis in fruits of the 21 date palm accessions studied.

\begin{tabular}{|c|c|c|c|c|c|}
\hline ACCNS & $\mathbf{C A}$ & MG & NA & $\mathbf{K}$ & PH \\
\hline R13P9 & $68.83 \pm 5.95^{f}$ & $35.38 \pm 5.93^{\mathrm{d}}$ & $6.6 \pm 0.57^{\mathrm{i}}$ & $307.67 \pm 0.88$ & $30.41 \pm 0.06^{\mathrm{n}}$ \\
\hline R16P31 & $78.52 \pm 5.73^{\text {cdef }}$ & $39.58 \pm 6.06^{\mathrm{d}}$ & $8.12 \pm 0.5^{\mathrm{g}}$ & $313 \pm 0.58^{1}$ & $29.4 \pm 0.06^{\circ}$ \\
\hline R6P20 & $85.33 \pm 5.72^{\text {bcdef }}$ & $60.34 \pm 0.39^{\mathrm{b}}$ & $7.7 \pm 0.06^{\mathrm{h}}$ & $311 \pm 0.58^{\mathrm{n}}$ & $32.72 \pm 0.06^{\mathrm{k}}$ \\
\hline R5P8 & $94.45 \pm 5.75^{\mathrm{bc}}$ & $57.3 \pm 0.54^{\mathrm{bc}}$ & $10.75 \pm 0.04^{\mathrm{d}}$ & $424 \pm 0.58^{\mathrm{a}}$ & $48.3 \pm 0.06^{\mathrm{a}}$ \\
\hline R3P22 & $88.88 \pm 5.74^{\text {bcde }}$ & $60.32 \pm 0.37^{\mathrm{b}}$ & $7.54 \pm 0.1^{\mathrm{h}}$ & $295 \pm 0.58^{q}$ & $24.82 \pm 0.06^{\mathrm{p}}$ \\
\hline $\mathrm{R} 5 \mathrm{P} 24$ & $102.47 \pm 5.75^{\mathrm{b}}$ & $78.41 \pm 0.52^{\mathrm{a}}$ & $11.77 \pm 0.07^{\mathrm{c}}$ & $404 \pm 0.58^{c}$ & $46.21 \pm 0.06^{\mathrm{c}}$ \\
\hline R1P18 & $69.77 \pm 5.78^{\mathrm{ef}}$ & $40.48 \pm 0.63^{\mathrm{d}}$ & $8.65 \pm 0.05^{\mathrm{f}}$ & $354 \pm 0.58^{\mathrm{g}}$ & $35.85 \pm 0.06^{\mathrm{h}}$ \\
\hline R7P1 & $70.49 \pm 5.75^{\text {ef }}$ & $35.16 \pm 0.52^{d}$ & $6.86 \pm 0.06^{\mathrm{i}}$ & $342 \pm 0.58^{\mathrm{h}}$ & $32.35 \pm 0.04^{1}$ \\
\hline $\mathrm{R} 14 \mathrm{P} 21$ & $84.52 \pm 5.56^{\text {bcdef }}$ & $56.12 \pm 0.53^{b c}$ & $10.14 \pm 0.08^{\mathrm{e}}$ & $385 \pm 0.58^{\mathrm{d}}$ & $35.75 \pm 0.06^{\mathrm{h}}$ \\
\hline R15P6 & $88.29 \pm 5.79^{\text {bcde }}$ & $56.61 \pm 0.59^{b c}$ & $7.43 \pm 0.05^{\mathrm{h}}$ & $312 \pm 0.58^{\mathrm{mn}}$ & $34.26 \pm 0.05^{\mathrm{j}}$ \\
\hline R4P29 & $76.82 \pm 5.8^{\text {cdef }}$ & $38.74 \pm 0.52^{\mathrm{d}}$ & $6.25 \pm 0.06^{\mathrm{j}}$ & $334 \pm 0.58^{\mathrm{i}}$ & $32.63 \pm 0.05^{\mathrm{k}}$ \\
\hline R5P6 & $76.38 \pm 5.81^{\text {cdef }}$ & $35.26 \pm 0.55^{\mathrm{d}}$ & $6.55 \pm 0.06 \mathrm{ij}$ & $297 \pm 0.58^{p}$ & $30.45 \pm 0.06^{\mathrm{n}}$ \\
\hline $\mathrm{R} 24 \mathrm{P} 9$ & $119.39 \pm 0.36^{\mathrm{a}}$ & $80.55 \pm 0.4^{a}$ & $13.44 \pm 0.05^{\mathrm{a}}$ & $423 \pm 0.58^{\mathrm{a}}$ & $46.8 \pm 0.06^{\mathrm{b}}$ \\
\hline ZARIYA & $76.23 \pm 5.81^{\text {cdef }}$ & $40.48 \pm 0.38^{\mathrm{d}}$ & $5.25 \pm 0.05^{\mathrm{k}}$ & $278 \pm 0.58^{r}$ & $30.76 \pm 0.29^{\mathrm{m}}$ \\
\hline R13P1 & $82.22 \pm 5.74^{\text {cdef }}$ & $52.1 \pm 0.52^{\mathrm{c}}$ & $6.73 \pm 0.01^{\mathrm{i}}$ & $365 \pm 0.58^{f}$ & $34.55 \pm 0.05^{\mathrm{i}}$ \\
\hline R13P5 & $72.35 \pm 5.83^{\mathrm{def}}$ & $34.37 \pm 0.45^{\mathrm{d}}$ & $6.2 \pm 0.06^{\mathrm{k}}$ & $316 \pm 0.58^{\mathrm{k}}$ & $30.4 \pm 0.06^{\mathrm{n}}$ \\
\hline $\mathrm{R} 2 \mathrm{P} 4$ & $72.23 \pm 5.89^{\mathrm{def}}$ & $39.26 \pm 0.5^{\mathrm{d}}$ & $6.74 \pm 0.03^{\mathrm{i}}$ & $275 \pm 0.58^{\mathrm{s}}$ & $29.5 \pm 0.06^{\circ}$ \\
\hline R9P12 & $92.7 \pm 5.76^{\mathrm{bc}}$ & $60.28 \pm 0.41^{\mathrm{b}}$ & $11.4 \pm 0.06^{\mathrm{c}}$ & $383 \pm 0.58^{\mathrm{e}}$ & $38.22 \pm 0.05^{\mathrm{e}}$ \\
\hline
\end{tabular}

Mean \pm standard error with different (s) letters in the same column are significantly differed at $\mathrm{P}>0.05$. 


\subsection{Sugar Content Analysis}

The main sugars in the date fruits analyzed in this study were Glucose, Fructose, and Sucrose. From the result, the glucose content was recorded to have no significant differences $(\mathrm{P} \geq 0.05)$ among the accessions. Accession R5P8 had the highest mean value of 320.11, while accession R4P29 had the lowest mean value of 30.36 .

The fructose content was highest in accession R15P6, with the mean value of $102.38 \mathrm{mg} / \mathrm{g}$ this value was significantly different from all other accessions. The least mean value for fructose was obtained in accession R4P26 with a mean of $32.20 \mathrm{mg} / \mathrm{g}$. This value was significantly different from all other accessions at $\mathrm{P} \geq 0.05$.

The result showed that the sucrose content was highest in accession R15P6 with the mean value of $92.56 \mathrm{mg} / \mathrm{g}$ which was significantly different from all other accessions at $\mathrm{P} \geq 0.05$, this was followed by accession R5P20 with the mean value of $90.00 \mathrm{mg} / \mathrm{g}$, while the least was observed in accession R4P29 with the mean value of $29.1 \mathrm{mg} / \mathrm{g}$ statistically.

Table 3. Sugar content in fruits of date flesh from 21 accessions ( $\mathrm{mg} / \mathrm{g}$ ).

\begin{tabular}{llll}
\hline Parameter & Glucose & Fructose & Sucrose \\
\hline R13P9 & $89.64^{\mathrm{b}}$ & $95.07^{\mathrm{c}}$ & $85.95^{\mathrm{c}}$ \\
R16P31 & $52.29^{\mathrm{b}}$ & $55.46^{\mathrm{k}}$ & $50.14^{\mathrm{k}}$ \\
R6P20 & $80.11^{\mathrm{b}}$ & $85.96^{\mathrm{d}}$ & $76.81^{\mathrm{d}}$ \\
R5P8 & $320.11^{\mathrm{a}}$ & $84.96^{\mathrm{d}}$ & $76.81^{\mathrm{d}}$ \\
R3P22 & $67.23^{\mathrm{b}}$ & $71.30^{\mathrm{f}}$ & $64.46^{\mathrm{f}}$ \\
R5P24 & $33.92^{\mathrm{b}}$ & $35.97^{\mathrm{n}}$ & $32.52^{\mathrm{n}}$ \\
R1P18 & $39.42^{\mathrm{b}}$ & $40.59^{\mathrm{m}}$ & $37.60^{\mathrm{m}}$ \\
R1P10 & $63.81^{\mathrm{b}}$ & $67.68^{\mathrm{g}}$ & $61.19^{\mathrm{gh}}$ \\
R7P1 & $41.83^{\mathrm{b}}$ & $44.37^{\mathrm{l}}$ & $40.11^{1}$ \\
R14P21 & $64.91^{\mathrm{b}}$ & $68.84^{\mathrm{g}}$ & $62.24^{\mathrm{g}}$ \\
R15P6 & $96.53^{\mathrm{b}}$ & $102.38^{\mathrm{a}}$ & $92.56^{\mathrm{a}}$ \\
R4P26 & $30.36^{\mathrm{d}}$ & $32.20^{0}$ & $29.11^{\mathrm{o}}$ \\
GPIV & $64.91^{\mathrm{b}}$ & $68.84^{\mathrm{g}}$ & $62.24^{\mathrm{g}}$ \\
R24P9 & $62.75^{\mathrm{b}}$ & $66.55^{\mathrm{h}}$ & $60.17^{\mathrm{h}}$ \\
ZARIYA & $56.19^{\mathrm{b}}$ & $59.59^{\mathrm{j}}$ & $53.88^{\mathrm{j}}$ \\
R9P2 & $68.11^{\mathrm{b}}$ & $73.81^{\mathrm{e}}$ & $67.24^{\mathrm{e}}$ \\
R5P20 & $94.13^{\mathrm{b}}$ & $99.83^{\mathrm{b}}$ & $90^{\mathrm{b}}$ \\
R13P1 & $58.83^{\mathrm{b}}$ & $62.39^{\mathrm{i}}$ & $56.41^{\mathrm{i}}$ \\
R13P5 & $50.88^{\mathrm{b}}$ & $53.96^{\mathrm{k}}$ & $48.78^{\mathrm{k}}$ \\
R2P4 & $56.19^{\mathrm{b}}$ & $59.59^{\mathrm{j}}$ & $53.88^{\mathrm{j}}$ \\
R9P12 & $55.37^{\mathrm{b}}$ & $58.72^{\mathrm{j}}$ & $53.09^{\mathrm{j}}$ \\
\hline
\end{tabular}

Mean \pm standard error with different (s) letters in the same column are significantly different at $\mathrm{P}>0.05$.

\section{Discussions}

\subsection{Proximate Composition}

The moisture content obtained was between $2.25 \%$ $7.65 \%$, which is similar to the report of [4] on date fruit varieties, but lower than those reported for coconut seeds $8.33 \pm 0.03$ [8]. However, moisture content of date palm depends on their harvesting time, maturation period and environmental conditions such as humidity and temperature in growing period and storage conditions [9]. The low moisture content indicate that date fruits can be stored for a long period of time without spoilage and it will not be susceptible to microbial growth and enzyme activities.

The ash content which is an index of mineral in most edible fruits was between 1.56-2.7, the variations observed in the ash content might be due to the differences in their nutritional attributes. The quantification of this result agrees with [10] who reported ash content of date fruits in the range of $1.4 \%-2.3 \%$. However, earlier studies reported ash content of various date fruits varieties ranging from $0.9 \%-2.0 \%$ [11]. High ash content in the studied accessions indicates the percentage of inorganic mineral elements present in date fruits.

The variations in protein content observed among the studied accessions was between $3.36-7.13$, which is contrary to the $2.85 \%$ of protein content observed in eleven Tunisian date fruits analyzed [12]. The result of protein content recorded in this study is higher than the average protein content of fresh and dried dates which were reported to be between $1.50-2.14 \%$ by [13], A considerable amount of protein in this studied accessions suggest that Nigerian date fruit could be of good potential for nutritional benefits.

Date fruit can be considered as a good source of dietary fiber such as cellulose, hemicellulose, lignin, pectin, etc. The fiber content recorded among the studied accessions was found to be between $2.1 \%-12.2 \%$, which is within the recommended average fibre intake. The variations in fibre content observed among the accessions might be due to varietal differences as well as duration of fruit collection. The crude fiber recorded in this study was within the range reported for two varieties of date palm of $6.63 \%-12.21 \%$ [14], 6.8\% on Cortinarius species of Mushroom (Peter and Tolulope, 2015). But higher than those reported by [10] in Omanian date fruits where $2.5 \%$ of fibre was recorded. Dietary fibre is known to influence digestion and absorption processes in the small intestine. Since the crude fibre value of date palm fruit is moderately high, if consumed it would aid digestion and absorption processes.

The low level of lipids content of $2.69 \%-5.46 \%$ recorded among the studied accessions is comparable with the means that, the date palm is safe for the heart and high blood pressure patients because it contains a low level of fatty acids and cholesterol.

The carbohydrate value of $64.55 \%-82.89 \%$ was obtained in this study, Variation in the carbohydrate concentration of date fruit can be attributed to differences in cultivar, harvest/postharvest factors and growing environment (Temperature, humidity, fertilizer use, etc.) [15-17]. However, the most important carbohydrate components in date fruit are glucose, fructose and sucrose, which can reach up to $70-80 \%$. Sugars are the most important constituents of dates, making them a rich source of energy for the human system. [12] Analyzed the main chemical components of date fruits from 11 Tunisian cultivars and found that they were rich in sugar (799.3-880.2 g kg-1 dry matter). Found that the 
total sugar concentration in Caqui 24 and Caqui 22 date fruits ranged from 424 to $542 \mathrm{~g} / \mathrm{kg}$ [23]. Saudi date varieties have been found to contain about $70 \%$ reducing sugars with an almost equal quantity of glucose and fructose as reported by [24]. This result shows that some Nigerian Date fruits are excellence sources of energy for metabolic processes and can utilized for confectionary products.

\subsection{Minerals Analysis}

The high level of calcium content (68.83-119.39) observed among the accessions is analogous to the $105.2 \%$ of calcium noticed in a study of nutritional evaluation and medicinal value of date palm collected from Sokoto and Zamfara states of Nigeria [4], but higher than $(60 \%, 55 \%$ and $51 \%)$ as reported on the Nutritional Analysis of three varieties Date Fruits (Phoenix dactylifera L.) in Perspective of Bangladesh [20]. Calcium have been reported to be themost abundant mineral in the body because it regulates many cellular processes and has important structural role in living organism, [14]. Calcium has been found to help keep muscles working correctly [25]. The high amounts of calcium observed among the accessions are indications that date fruits are good sources of bone strength and growth.

Magnesium is the best supporting actor needed every day in human health as it plays an important part of human bone by keeping muscles and nerves healthy. The magnesium value of 39.16-78.41 was obtained in this study, which fall within the recommended daily intake. This result agrees with the findings of [23] on medjool date cultivar, [12] on some Moroccan date fruit varieties. The report of this study revealed that regular consumption date fruits could help in supporting vascular function maintains proper body growth and facilitates mobility of the bones.

The sodium contents are relatively low (6.2\%-13.44\%) when compared with $38.55 \%$ of sodium obtained on some Nigerian date fruits (19), $91.03 \mathrm{~b} \%$ and $89.58 \%$ ontwo different varieties of unripe date palm (14).

However, the concentration of potassium in this study was found to be between $275 \%-424 \%$. [14] Stated in their report that an increased potassium and decreased sodium level was beneficial for the people suffering from hypertension, this agrees with the findings obtained in this study.

\subsection{Sugars Content Analysis}

Date palm fruit is characterized by its high content of sugars as shown in table (Table 3 ). The total sugars analyzed in this study were reducing (Glucose and fructose) and non reducing (sucrose) sugars. The richness of these studied date fruit accessions in reducing sugars suggests the existence of pronounced invertase activity, which considerably reduces its sucrose content.

The glucose content (30-96) in the date fruits obtained from this study is higher than that reported by [23] who reported $37.21 \%$ on glucose content on medjool variety in Mexico, and $37.79 \%$ glucose content recorded in some Moroccan date fruits as reported by [25]. Though this comparable to that of Shea fruit pulp studied in Uganda by [26]. This variation in glucose content may be due to differences in climate, soil, and other environmental conditions.

Glucose is an important energy source that is needed by all the cells and organs in human bodies. The considerable amount of glucose recoded in this study is an indication that Nigeria date fruits are excellent source for consumption which may aid in easy digestion in human cells and usefulfor getting the energy for metabolic processes.

The high amount of fructose recorded among the studied date fruit accessions was between (32-102), which is higher than glucose contents in the studied accessions. This is similar to the report of [27] who reported that fructose is about twice as sweet as glucose and it is considered less diabetogenic. However, the low glycemic index (GI) in dates have been reported to be due to high amount of fructose present [22]. This implies that consumption of date fruits may be very useful in the management of patients with diabetes.

However, it was observed that the sucrose content was lower than the glucose and fructose content in all the accessions. This agrees with the report of [28] on Tunisian dates who opined that as the fruit ripens there is reduction in sucrose and further increase in glucose and fructose which might be due to increasing activity of the invertase enzyme that converts sucrose into reducing sugars. This also agrees with the report of [29] on Iranian dates, that sucrose undergoes a complete hydrolysis, especially at Tamar stage which is also the fruiting stage of the date accessions studied.

\section{Conclusion}

This study has revealed the presence of the Nigerian date fruit. It has the further confirmed that the date palm fruit could be considered as an almost ideal food that provides a wide range of essential nutrients with many potential health benefits. The result of sugar contents shows that the Nigerian date are a great source of energy, due to their high sugar content in the pulp. This could be used as a substitute for sugar in the food industry. Also, the mineral content in the date sample is a good source of potassium, calcium and sodium, phosphorus and magnesium.

The date palm accessions studied would serve as a baseline for selection in current and future breeding programmes.

\section{References}

[1] SaadaM Al-Orf., Mona H M Ahmed., Norah Al-Atwai, Huda Al-Zaidi., Asma Dehwah, and Sumayyah Dehwah. (2012). Nutritional Properties and Benefits of the Date Fruits (Phoenix dactylifera L.). Review: Bulletin of the National Nutrition Institute of the Arab Republic of Egypt, (39) 97.

[2] Franz, A., Jörn, B. and UdoCenskowsky, P. (2002). Date Palm Natural, 1st edition. 
[3] Vayalil, P. K. (2002). Antioxidant and antimutagenic properties of aqueous extract of date fruit (Phoenix dactylifera L. Arecaceae). Journal of Agriculture and Food Chemistry, 50: $610-7$.

[4] Sadiq, S. IzuagieT., Shuaibu, M., Dogoyaro, A, Garba, A., Abubakar, S. (2013). The Nutritional Evaluation and Medicinal Value of Date Palm (Phoenix dactylifera) International Journal of Modern Chemistry, 4 (3), 147-154.

[5] Okolo E. C., Okwuagwu C. O. and Ataga C. D. (2005). Prospect of date plantation establishment in Nigeria. Journal of Agric forestry and fisheries, 6: 1: 24-28.

[6] Ataga, C. D., Hamza M. A, A. O. Yusuf (2012). Status Of Date Palm (Phoenix dactylifera L.) Genetic Resources in Nigeria. International journal of life science and pharma research, 2 (2), 46-51.

[7] Galant, Kaufman \& Wilson, (2015). Glucose: detection and analysis. Food Chemistry. 188: 149-160.

[8] Ojobor CC, Anosike CA, Ezeanyika LUS. (2018). Evaluation of Phytochemical, Proximate and Nutritive Potentials of Cocos nucifera (Coconut) Seeds. Journal of Experimental Research, 2 (6), 2.

[9] Crisan EV, Sands A. (1978). Nutritional value. New York: Academic Press.

[10] Al-Harrasi, A., Rehman, N. U., Hussain, J., Khan, A. L., AlRawahi, A., Gilani, S. A., M. Al-Broumi. and L. Ali. (2014). Nutritional assessment and antioxidant analysis of 22 date palm (Phoenix dactylifera) varieties growing in Sultanate of Oman. Asian Pacific Journal Tropical Medicine, 7: 591-598.

[11] Ghnimi, S, Syed Ume, A, Eldin, A. (2017). Date fruit (Phoenix dactylifera L.): An underutilized food seeking industrial valorization. NFS journal, pp 1-10.

[12] Borchani Chema., Souhail Besbes, Christophe Blecker, Manel Masmoudi, Rochdi Baati and Hamadi Attia. (2010). Chemical properties of 11 date cultivars and their corresponding fiber extracts, African Journal of Biotechnology, 9 (26), 4096-4105.

[13] Kazi N. A., Yadav J. P. and Agale M. G. (2015). Nutritional value of fruits. Scholarly Research Journal for Interdisciplinary Studies, 2937-2943.

[14] Thilagavathiand Gayathri. (2019). Comparison of physicochemical and functional properties of two different varieties of unripe date palm. Journal for all Subjects, 8 (6) 17.

[15] Baliga, M. S., B. R. V. Baliga, S. M. Kandathil, H. P. Bhat and P. K. Vayalil. 2011. A review of the chemistry and pharmacology of the date fruits (Phoenix dactylifera. Food Research International. 44: 1812-1822.

[16] Saafi, E. B., A. E. Arem, M. Issaoui, M. Hammamiand L. Achour. 2009. Phenolic content and antioxidant activity of four date palm (Phoenix dactylifera L.) fruit varieties grown in Tunisia. International Journal of Food Science and Technology. 44: 2314-2319.

[17] Hasnaou, A., Elhoumaizi, M. A., Hakkou, A., Wathelet, B., Sindic, M. (2011). Physicochemical Characterization,
Classification and Quality Evaluation of Date Palm Fruits of some Moroccan Cultivars. Journal of Scientific Research, 3 (1), 139-149.

[18] Amoros, A., M. T. Pretel, M. S. Almansa, M. A. Botella, P. J. Zapata and M. Serrano. (2009). Antioxidant and nutritional properties of date fruit from Elche grove as affected by maturation and phenotypic variability of date palm. Journal of Food Science and Technology. 15: 65-72.

[19] Mikki MS. (1999). Date palm post harvest processing technology in Saudi Ara-bia. Iran: Regional Workshop on Date Palm Post harvest Processing Technology.

[20] Sultana, P., Dilruba, E., Afzal, S., Mrityunjoy, B., Subed, C. S., Md. G. S. J., Md A. I., Narayan, R., Mohammad., S. S (2015). Nutritional Analysis of Date Fruits (Phoenix dactylifera L.) in Perspective of Bangladesh. American Journal of Life Sciences, 3 (4), 274-278.

[21] Elsohaimy S., Abdelwahab A., Brennan C., Aboueleinin. (2015) A. Phenolic content, antioxidant and antimicrobial activities of Egyptian date palm (Phoenix dactylifera L.) fruits. Australian. Journal of. Basic and Applied Sciences, 9, 141.

[22] Miller, C. J., Dunn, E. V. and Hashim, I. B. (2003). The glycaemic index of dates and date/yoghurt mixed meals. Are dates 'the candy that grows on trees'? Eur. J. Clin. Nutr., 57: 427-30.

[23] Ricardo S. T, NoÈ O. U, BenjamÌn V. S, Navor, R. G, Conrado, G. 1, Daniel, C, Iv·n C. G, Laura D. R, MarÌa P, Haro, V. J, Luis M. M, Antonio M. M, Padmanabhan, M and Robert K. (2019). Nutritional assessment, phytochemical composition and antioxidant analysis of the pulp and seed of medjool date grown in Mexico. Peer journal, 1-19.

[24] Omowunmi, Solaand AdejumoAyoade. (2013). Nutritional Composition of the Fruit of the Nigerian Wild Date Palm, Phoenix dactylifera. World Journal of Dairy \& Food Sciences 8 (2): 196-200.

[25] Bouhlali, E. T., Chakib Alem (2015). Phytochemical compositions and antioxidant capacity of three date seeds varieties grown in the South East Morocco. Journal of the Saudi Society of Agricultural Sciences.

[26] Prokarite La Base de Donnees, Vitellaria, World Agroforestry Centre, 2007. Accessed on 19.3.07. http://prokarite.org/Vitellaria-dbase/fat-percentage.html.

[27] Biglari, F., A. F. M. AlKarkhi and A. M. Easa. 2008. Antioxidant activity and phenolic content of various date palm (Phoenix dactylifera) fruits from Iran. Food Chemistry, 107: 1636-1641.

[28] Amira, E. A., F. Guido, S. E. Behija, I. Manel, Z. Nesrine, F. Ali, H. Mohamed, H. A, Noureddine and A. Lotfi. 2011. Chemical and aroma volatile compositions of date palm (Phoenix dactylifera $\mathrm{L}$.) fruits at three maturation stages. Food Chemistry, 127: 744-1754.

[29] Rastegar, S., M. Rahemi, A. Baghizadeh and M. Gholami. 2012. Enzyme activity and biochemical changes of three date palm cultivars with different softening pattern during ripening. Food Chemistry, 134: 127-1286. 